\title{
支配従属構造照合による文と名詞句の前方照応解析
}

\author{
吉見 毅彦 ${ }^{\dagger}$ Jiri Jelinek ${ }^{\dagger \dagger}$
}

本稿では, 文とその後方に位置する名詞句との照応を, 複雑な知識や処理機構を用い ず，表層的な情報を用いた簡単な処理によって解析する方法を提案する，文と名詞句 の構文構造を支配従属構造で表現し，それらの構造照合を行ない，照合がとれた場合， 照応が成立するとみなす，構造照合に用いる規則は, 文が名詞句に縮約されるときに 観察される現象のうち, 主に, 用連助詞から体連助詞への変化, 情報伝達に必須でな い語の削除に着目して定義する．このような簡単な処理によって前方照応がどの程度 正しく捉えられるかを検証するための実験を, サ変動詞が主要部である文と, そのサ 変動詞の語幹が主要部である名詞句の組を対象として行なった。実験では, 新聞記事 から抽出した 178 組のうち 133 組 $(74.7 \%)$ について, 本手法による判定と人間による 判定が一致した。 また, 構造照合で類似性が最も高いと判断された支配従属構造の組 を優先解釈として出力することによって, 入力の時点で一組当たり平均 3.4 通り存在 した曖昧性が 1.8 通りへ絞り込まれた。

キーワード： 照応, 支配従属構造, 構造照合, 曖昧性解消

\section{Anaphora Resolution of Sentences and Noun Phrases by Matching Dependency Structures}

\author{
TAKEHIKo YOSHIMI $^{\dagger}$ and JIRI JELINEK ${ }^{\dagger \dagger}$
}

We propose a simple method of analysing correferentiality between sentences and later occurring noun phrases. Our method uses surface information and requires no complex data or processing mechanism. We represent a sentence and a later occurring noun phrase as dependency structures, and examine whether the two structures are matched. Where a matching between them can be established, we assume that the two are correferential. The rules for establishing structural matching are part of the paradigm of theme packing, namely the predictable changes of adverbal particles into adnominal particles and the disappearance of some non-essential information. In order to ascertain to what degree anaphora can be correctly traced by such simple processing, we have carried out an experiment centred upon sentences governed by a verb of the SAHEN category and later occurring noun phrases in which the head noun is formally identical with the invariable part of the SAHEN verb. Of the 178 pairs of such sentences and noun phrases selected from newspaper articles, 133 pairs $(74.7 \%)$ were correctly identified as correferential or otherwise, in accordance with human judgement. Furthermore, as a side effect, the number of dependency structures to be considered can be reduced by selecting only the pairs of dependency structures with the best affinity through structural matching. By this method the average 3.4-fold structural ambiguity was reduced to average 1.8 -fold.

KeyWords: Correference, Dependency, Structural Matching, Disambiguation 


\section{1 はじめに}

適格なテキストでは，通常，テキストを構成する要素の間に適切な頻度で照応が認められる. この照応を捉えることによって，テキスト構成要素の解釈の良さへの裏付けや，解釈の曖昧性 を解消するための手がかりが得られることが多い。例えば，次のテキスト 1 の読み手は,「新自 由クラブは，奈良県知事選で自民党推萀の奥田氏を支持する」で触れた事象に，「知事選での奥 田氏支持」が再び言及していると解釈するだろう。

テキスト 1 新自由クラブは，奈良県知事選で自民党推萀の奥田氏を支持する方針をようやく 固めた．知事選での奥田氏支持に強く反対する有力議員も多く，決定が今日まで ずれ込んでいた。

この照応解釈は,「奈良県知事選で」が「支持する」と「固めた」のどちらに従属するかが決定さ れていない場合には，この曖昧性を解消するための手がかりとなり，何らかの選好に基づいて 「支持する」に従属する解釈の方が既に優先されている場合には，この解釈の良さを裹付ける.

このようなことから，これまでに，前方照応を捉えるための制約 (拘束的条件) と選好 (優先 的条件) が Text-Wide Grammar (Jelinek, Yoshimi, Nishida, Tamura, and Murakami 1995) な どで提案されている. Text-Wide Grammar によれば，テキスト 1 でこの照応解釈が成立する のは,「新自由クラブは，奈良県知事選で自民党推薦の奥田氏を支持する」を $X$,「知事選での奥 田氏支持」を $Y$ としたとき，これらが次の三つの制約を満たすからである.

構文制約 $Y$ は，ある構文構造上で $X$ の後方に位置する ${ }^{1}$.

縮約制約 $Y$ は， $X$ を縮約した言語形式である。

意味制約 $Y$ の意味は， $X$ の意味に包含される.

あるテキスト構成要素 $X て ゙$ 触れた事象に他の要素 $Y$ が再言及しているかどうかを決定するため には， $X$ と $Y$ がこれの制約を満たすかどうかを判定するための知識と機構を計算機上に実装 すればよい，実際，構文制約と縮約制約については，実装できるように既に定式化されている。 これに対して，意味制約が満たされるかどうかを具体的にどのようにして判定するかは，今後 の課題として残されている.

意味制約が満たされるかどうかを厳密に判定することは，容易ではない，厳密な判定を下す ためには， $X$ と $Y$ 両方またはいずれか一方が文や句である場合, その構文構造とそれを構成 する辞書見出し語の意味に基づいて全体の意味を合成する必要がある。テキストの対象分野を 限定しない機械翻訳などにおいて，このような意味合成を実現するためには，膨大な量の知識 や複雑な機構を構築することが必要となるが, 近い将来の実現は期待しがたい.

†シャープ (株) 情報商品開発研究所 / 神戸大学 大学院自然科学研究科, Information Systems Product Development Laboratories, SHARP Corp. / Graduate School of Science and Technology, Kobe University

十† 元 シャープ (株) 情報商品開発研究所, Formerly, Information Systems Product Development Laboratories, SHARP Corp.

$1 X$ と $Y$ が言語心理学的なある一定の距離以上離れていると, $Y$ は $X$ を指せないことがあると考えられるが, 距離に関 する制約は構文制約に含まれていない。 
本稿では，近い将来の実用を目指して，構築が困難な知識や機構を必要とする意味合成によ る意味制約充足性の判定を, 表層的な情報を用いた簡単な構造照合による判定で近似する方法 を提案する、基本的な考え方は, 構文制約と縮約制約を満たす $X$ と $Y$ について，それぞれの構 文構造を支配従属構造で表し，それらの構造照合を行ない，照合がとれた場合，Xの意味が $Y$ の意味を包含するとみなすというものである，もちろん，単純な構造照合で意味合成が完全に 代用できるわけではないが，本研究では，日英機械翻訳への応用を前提として，簡単な処理に よって前方照応がどの程度正しく捉えられるかを検証することを目的とする．以降，本稿の対 象を, サ変動詞が主要部である文 (以降, サ変動詞文と呼ぶ) $X$ とし, そのサ変動詞の語幹が 主要部であり $X$ の後方に位置する名詞句 (サ変名詞句) $Y$ とした場合 2 に限定する.

これまでに, 性質の異なる曖昧性がある二つの構文構造を照合することによって互いの曖昧 性を打ち消す方法に関する研究が行なわれ，その有効性が報告されている (稲垣博人, 壁谷喜義, 小橋史彦 1988; 宇津呂武仁, 松本裕治, 長尾畺 1992; Kinoshita, Shimazu, and Hirakawa 1993; 那須川哲哉 1995). 本稿の対象であるサ変動詞文とサ変名詞句にも互いに性質の異なる曖昧性 があるので, 構造照合を行ない, 類似性が高い支配従属構造を優先することによって, サ変動 詞文とサ変名詞句の両方または一方の曖昧性が解消される，例えば，サ変名詞句「奥田氏支持」 から得られる情報だけでは「奥田氏」と「支持」の支配従属関係を一意に決定することは難し いが，テキスト 1 では，サ変動詞文「奥田氏を支持する」との構造照合によって，サ変名詞句 を構成する要素間の支配従属関係が定まる.

このように, サ変名詞句の曖昧性解消に，サ変名詞句の外部から得られる情報を参照するこ とは有用である。一方，複合名詞の内部から得られる情報に基づく複合名詞の解析法も提案さ れている (小林義行, 徳永健伸, 田中穂積 1996). 複合名詞の主要部がサ変名詞である場合, こ れら二つの方法を併用することによって, より高い解析精度の達成が期待できる.

2 節では, サ変動詞文とサ変名詞句の支配従属構造を照合するための規則を記述する． 3 節 では，構造照合規則に従って照応が成立するかどうかを判定する手順について述へ，処理例を 挙げる. 4 節では, 新聞記事から抽出したサ変動詞文とサ変名詞句の組を対象として行なった 実験結果を示し，照応が正しく捉えられなかった例についてその原因を分析する.

\section{2 サ変動詞文とサ変名詞句の構造照合規則}

サ変動詞文がサ変名詞句に縮約されるときに観察される現象のうち次の現象に着目して，サ 変動詞文とその後方に位置するサ変名詞句の間で照応が成立するときに従うべき規則を定める.

サ変動詞とその従属語を関係付ける助詞 (以降, 用連助詞と呼ぶ) は, その支配従属 関係を保ったまま，サ変名詞とその従属語を関係付ける助詞 (体連助詞) に変化する.

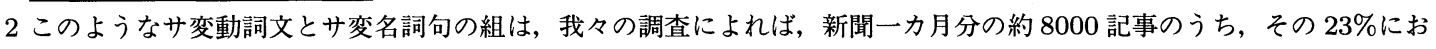
いて見られた。 
（2） サ変動詞文でのサ変動詞の態の区別は，サ変名詞句では制限されるか，あるいは行な われなくなる。

（3） サ変名詞句では，サ変動詞の従属語のうち，情報伝達に必須である語のみが，サ変動 詞文での出現順序に因われない順序で表現される。

\section{1 用連助詞から体連助詞への変化}

サ変動詞文がサ変名詞句に縮約されるとき，サ変動詞文におけるサ変動詞とその従属語の支 配従属関係は，サ変名詞句におけるサ変名詞とその従属語の支配従属関係として保存される，た だし，サ変動詞と従属語を関係付ける用連助詞は，規範に従って，サ変名詞と従属語を関係付 ける体連助詞に置き換えられるか，あるいは表現されなくなる，例えば，サ変動詞文「奥田氏 を支持する」における用連助詞「を」が体連助詞「の」またはゼロ形態素に変化することによっ て，それぞれ，サ変名詞句「奥田氏の支持」または「奥田氏支持」に縮約される，用連助詞から 体連助詞への変化は, 一般に, 表 1 に示す対応に従う。動詞あるいは動詞型に固有の変化, 例 えば,「イラク説得の成功を期待する」から「成功への期待」への縮約に見られる用連助詞「を」 から体連助詞「への」への変化は，表 1 の対応とは別に，動詞あるいは動詞型毎に記述する.

規則 1 用連助詞は，それが表す支配従属関係と深層的に同じ支配従属関係 ${ }^{3}$ 表す体連助詞に 変化する，その変化は，動詞固有の対応が記述されていれば，それに従い，さもなけ れば表 1 に従う。

表 1 用連助詞と体連助詞の対応 (抜粋)

\begin{tabular}{|c|c|c|}
\hline 用連助詞 & 支配従属関係 & 体連助詞 \\
\hline$\overline{~ מ ゙ ~}$ & Subject & にによる, の, $\phi^{\dagger}$ \\
\hline で & $\begin{array}{l}\text { Instrument } \\
\text { PlaceActive }\end{array}$ & $\begin{array}{l}\text { での, による, の, } \phi \\
\text { での, における, の, } \phi\end{array}$ \\
\hline と & $\begin{array}{l}\text { Company } \\
\text { Quotation }\end{array}$ & $\begin{array}{l}\text { との, の, } \phi \\
\text { との, の, } \phi\end{array}$ \\
\hline に & $\begin{array}{l}\text { Agent } \\
\text { PlaceStatic } \\
\text { Target }\end{array}$ & $\begin{array}{l}\text { による, の, } \\
\text { での, における, の, } \phi \\
\text { への, までの, に対する, の, } \phi\end{array}$ \\
\hline 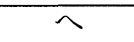 & Target & への, までの, に対する, の, $\phi$ \\
\hline を & $\begin{array}{l}\text { Object } \\
\text { PlaceOfTransit }\end{array}$ & $\begin{array}{l}\text { に対する, の, } \phi \\
\text { 上の, の, } \phi\end{array}$ \\
\hline
\end{tabular}

†記号 $\phi$ はゼロ形態素を意味する.

3 本稿で行なっている支配従属関係の区別は，比較的浅い深層度での区別である．例えば，助詞「が」と「に」が表す支 配従属関係の一つは, より深い層では共に “動作主”になりえるが,ここではSubject, Agent という別の関係として いる。その理由は, 本稿での区別は日英機械翻訳での利用を前提としたものであり, この限りにおいて, 表層表現をよ り深い層へ写像する必要はないからである。 


\section{2 態の区別の制限}

サ変動詞文では, サ変動詞に接続する助動詞によって, 能動態, 受動態, 使役態, 間接受動 態, 可能態と, これらの組合せ (受動使役態など) が区別される。これに対して, サ変名詞句で は，態の区別が制限されるか，あるいは行なわれなくなる，例えば，次のテキスト 2 では，サ 変動詞文「日本ではアジア人が差別される」が受動態であったことは，サ恋名詞句「足元にい るアジア人に対する差別」では表現されていない.

テキスト 2 日本ではアジア人が差別されるのは当然だという考え方が強い. 日本にとって国 際化とは，足元にいるアジア人に対する差別を撤廃して，一緒に手を組んで生き てゆくことだと思う.

表 1 の対応は, サ変動詞の態が能動である場合の対応である. 従って, サ変動詞が能動態で ない場合，用連助詞から体連助詞への変化が規則 1 に従うかどうかを調べる前に，サ変動詞の 態を能動態に戻しておく必要がある.

規則 2 サ変動詞の態が能動でなければ，サ変動詞とその従属語との支配従属関係は表 2 に示 す対応に従って変化する.

表 2 能動態への還元に伴う支配従属関係の変化

\begin{tabular}{|l|lll|}
\hline \multicolumn{1}{|c|}{} & \multicolumn{3}{c|}{ 支配従属関係の変化 } \\
\hline \hline 受動 & Subject & $\Longrightarrow$ & Object \\
& Agent & $\Longrightarrow$ & Subject \\
\hline 使役 & Agent & $\Longrightarrow$ & Subject \\
\hline 間接受動 & Subject & $\Longrightarrow$ & IndirectObject, Target $\}^{\ddagger}$ \\
& Agent & $\Longrightarrow$ & Subject \\
\hline 可能 & PotentialObject & $\Longrightarrow$ & Object \\
\hline
\end{tabular}

‡ IndirectObject か Target かは動詞型による.

\section{3 情報伝達に必須でない従属語の削除}

サ変動詞の従属語のうち, 情報伝達に必須でない語は, サ変名詞句では表現されなくなる。 また，削除されずに残ったサ変名詞の従属語の出現順序は，サ変動詞文におけるサ変動詞の従 属語の出現順序に一致するとは限らない，例えば，サ変動詞文「新自由クラブは，奈良県知事 選で自民党推鷹の奥田氏を支持する」は，1）すべての語を元の出現順序のままで表現した「新 自由クラブによる奈良県知事選での自民党推萀の奥田氏の支持」から，2）「新自由クラブ」と 「自民党推薦」が削除され，「奈良眢知事選」と「奥田氏」の出現順序が交替した「奥田氏に対す る奈良県知事選での支持」などを経て，3）サ変名詞以外の語をすべて削除した「支持」に至る まで，様々なサ変名詞句に縮約されうる。 
「奈良県知事選で支持する」から「知事選での支持」への縮約における「奈良県知事選」か ら「知事選」への変化に見られるように, 情報伝達に必要でない従属語は, 語全体ではなくそ の部分が削除されることがある. 従属語 (名詞) は, 〈〈接頭語 $\left.\rangle^{*}\langle\text { 語基 }\rangle^{+}\langle\text {接尾語 }\rangle^{*}\right\rangle^{+}$という 構成 ${ }^{4}$ をており，語の主要部は最後尾の語基である．従属語の一部が削除されるとき，まず削 除されるのは主要部以外の部分であり, 語の主要部である最後尾の語基は最後まで削除されず に残る場合が多いので，次のような規則をおく.

規則 3 サ変名詞の従属語は, サ変動詞のいずれかの従属語から接尾語を除いた部分に後方文 字列一致する。

\section{3 構造照合による意味合成の近似}

2 節で述べた構造照合規則を用いたサ変動詞文とサ変名詞句の照応判定は, 困 1 に示す手順 に従って行なう。この手順に従う処理によって照応が成立すると判定される例, 成立しないと 判定される例を示す.

ステップ 1 サ変動詞文を含む文の支配従属構造から, サ変動詞とその直接従属語 で構成される支配従属構造を抽出する。サ変名詞句を含む文の支配従属構造から， サ変名詞とその直接従属語で構成される支配従属構造を抽出する.

ステップ 2 サ変名詞句の支配従属構造のすべてがサ変名詞のみで構成されていれ ば，照応が成立するものとして処理を終える．さもなければ，开変名詞句の各支 配従属構造を $Y_{1}, Y_{2}, \ldots, Y_{n}$ とする。

ステップ 3 サ変動詞文の支配従属構造におけるサ変動詞と従属語との支配従属関係 を規則 2 に従って書き換えた支配従属構造を $X_{1}, X_{2}, \ldots, X_{m}$ とする.

ステップ $4 \quad X_{i}(1 \leq i \leq m)$ と $Y_{j}(1 \leq j \leq n)$ のすべての対 $\left[X_{i}, Y_{j}\right]$ について，そ れぞれ, ステップ 4.1 と 4.2 に従ってマッチング問題を解き, 各最大マッチング $M_{i, j}$ とその評価点 $S_{i, j}$ を求める.

ステップ $4.1 X_{i}$ における従属語 $X d e p_{i, k}$ と支配従属関係を表す助詞 $X r e l_{i, k}$ の対 $\left\langle X\right.$ dep $\left._{i, k}, X r e l_{i, k}\right\rangle$ を一方の頂点, $Y_{j}$ における従属語と助詞の対 $\left\langle Y\right.$ dep $\left._{j, l}, Y_{r e l} l_{j, l}\right\rangle$ を他方の頂点とし, 用連助詞 $X r e l_{i, k}$ と体連助詞 $Y r e l_{j, l}$ が規則 1 に従うとき, 三 つの頂点を辺で結び, 二部グラフを構成する.

ステップ 4.2 辺で結ばれている二つの頂点の従属語 $X \operatorname{dep}_{i, k}$ と $Y d e p_{j, l}$ が規則 3 に 従うとき, どの頂点も高々一つの組にしか属さないように，これら二つの頂点を 一つの組にする. 可能なマッチングのうち, 組の数が最も多いものを $\left[X_{i}, Y_{j}\right]$ につ いての構造照合結果 $M_{i, j}$ とする． $M_{i, j}$ の評価点 $S_{i, j}$ は, より多くの頂点が対応付 けられるほど良いという単純な基準に基づき， $M_{i, j}$ に含まれる組の数とする.

ステップ 5 ステップ 4 で得られた各評価点 $S_{i, j}$ の最大值 $S$ を求める. $S$ が正ならば, 照応が成立すると判定し， $S$ をえるマッチング $M$ を返す。ささもなければ，照応 が成立しないと判定する。

\section{図 1 サ変動詞文とサ変名詞句の構造照合の手順}

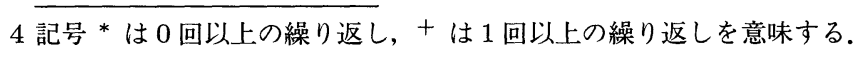


照応が成立すると判定される例として，1 節のテキスト 1 を処理する過程を追う。サ変動 詞文を含む文とサ変名詞句を含む文に対して形態素, 構文, 意味的共起解析を行ない, 可能な 支配従属構造のうち, 形態素, 構文, 意味的共起に関する選好による総合評価点が最も高い構 造を入力とすると, テキスト 1 の場合, 図 2 に示すように, サ変動詞文の支配従属構造が 3 通 り, サ変名詞句の支配従属構造が 2 通り抽出される 5 . 抽出されたサ变名詞句の支配従属構造を $Y_{1}, Y_{2}$ とする.また, 抽出されたサ変動詞は能動態であり, 規則 2 に従って支配従属関係を書 き換える必要はないので, 抽出されたサ変動詞文の支配従属構造をそのまま $X_{1}, X_{2}, X_{3}$ とする. $X_{1}$ は, 「支持する」が「新自由クラブは」と「奈良県知事選で」と「奥田氏を」を支配する解釈, $X_{2}$ は, 「支持する」が「奈良県知事選で」と「奥田氏を」を支配し，第一文の主動詞「固めた」 が「新自由クラブは」を支配する解釈， $X_{3}$ は,「支持する」が「奥田氏を」を支配し，「固めた」 が「新自由クラブは」と「奈良県知事選で」を支配する解釈である，また，Y $Y_{1}$ は, 「支持」が「知 事選での」と「奥田氏を」を支配する解釈， $Y_{2}$ は,「支持」が「奥田氏」を支配し，「奥田氏」が 「知事選での」を支配する解釈である。

サ変動詞文の支㳡従属構造 : X1, X2, X3

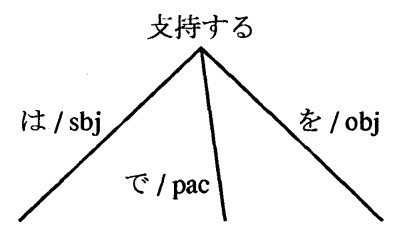

新自由クラブ
奈良県知事選 奥田氏

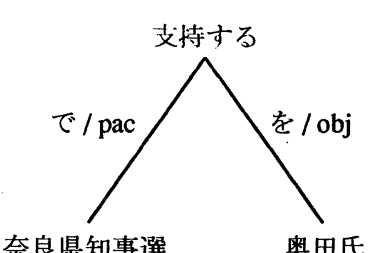

奥田氏

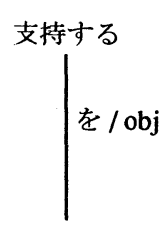

奥田氏

サ変名詞句の支配従属構造 : Y 1, Y 2

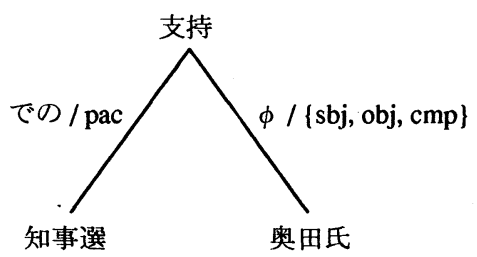

sbj : Subject, obj : Object, pac : PlaceActive, cmp:Company

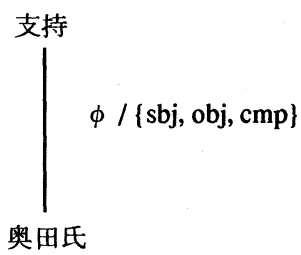

奥田氏

図 2 テキスト 1 から抽出される支配従属構造

5 語の従属先の曖昧性は個別の支配従属構造で表現するが，支配従属関係の曖昧性は，重複が許されていない支配従属関 係の重複が生じない限り，一つの支配従属構造上にまとめて表現する。テキスト 1 のサ変名詞句の支配従属構造を展開 すれば, $6(=3+3)$ 通りになる。 
ステップ 4 で， $X_{1}, X_{2}, X_{3}$ と $Y_{1}, Y_{2}$ の組合せから成る 6 通りの対について，それぞれマッ チング問題を解く. 頂点の支配従属関係が集合として表されている場合, 支配従属関係の集合 の交わりが空でないときに限り二つの頂点が辺で結べることにすると，対 $\left[X_{1}, Y_{1}\right]$ について の処理では，図 3 に示すように， $X_{1}$ の二つの頂点〈新自由クラブ, は/Subject〉, 〈奥田氏, を /Object〉を $Y_{1}$ の頂点 〈奥田氏, $\phi /\{$ Subject, Object, Company $\left.\}\right\rangle$ と結び， $X_{1}$ の頂点〈奈良県知 事選, で/PlaceActive〉を $Y_{1}$ の頂点〈知事選, での/PlaceActive〉と結んだ二部グラフが構成でき る.この二部グラフでは, 実線の辺で結ばれている頂点を組にすることによって, 評価点 2 点 の最大マッチングが得られる，なお，辺で結ばれている頂点を組にしたとき，頂点の支配従属 関係は元の集合から集合の交わりに変化する．他の対についても同様に処理すると，対 $\left[X_{1}, Y_{1}\right]$ と $\left[X_{2}, Y_{1}\right]$ から得られる最大マッチングが全体で最も評価点が高いマッチングとなる.

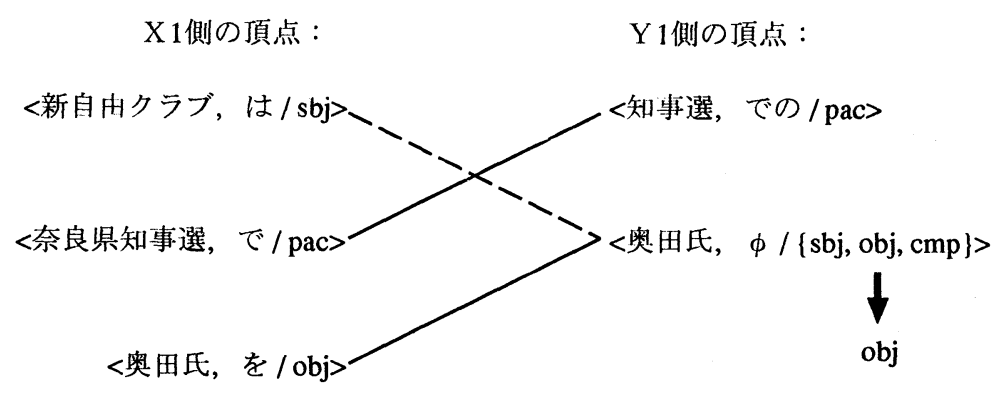

図 3 支配従属構造 $X_{1}$ と $Y_{1}$ における最大マッチング

全体で最も評価点が高いマッチングが得られる支配従属構造の対を優先させることによっ て，サ変動詞文とサ変名詞句の両方または一方の曖昧性を絞り込むことができる， $X_{1}$ と $Y_{1}$ の 構造照合の結果, 図 3 の最大マッチングが得られることから，Y底におる「奥田氏」と「支

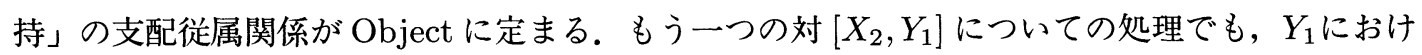
る「奥田氏」と「支持」の支配従属関係が一意に定まる. 従って, テキスト 1 の場合, 全体で $18(=3 \times 6)$ 通りの可能性を 2 通りに絞り込めたことになる.

次のテキスト 3 を対象とした処理では, サ変動詞文「大統領がリトアニアに対する強硬手段 を停止する」とサ変名詞句「ECによる援助の停止」の間に照応は成立しないと判定される.

テキスト 3 ソ連軍による弾圧は, 大統領がリトアニアに対する強硬手段を停止するとの 方針を明らかにした直後に起きた。これに対しベルギー外務省筋は ECによる援助の停止もあり得ると語っている.

サ変動詞文の支配従属構造としては,「停止する」が「大統領が」を支配する場合とそうでない 場合の 2 通りが可能であり, サ変名詞句の支配従属構造としては, 「停止」が「ECによる」を 支配する場合とそうでない場合の 2 通りが可能であるので, 支配従属構造の各対について規則 
1 に従う頂点を辺で結ぶと, 図 4 に示すような 4 通りの二部グラフが構成できる. しかし，い ずれの二部グラフにおいても規則 3 に従う頂点が存在しないので, 組が構成できない. 従って, サ変動詞文とサ変名詞句の間に照応は成立しないと判定される.

二部グラフ(1) :

<大統領，が/sbj> - - <EC，による/sbj>

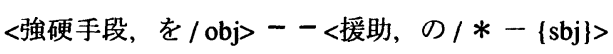

二部グラフ $(3)$ :

$<\mathrm{EC}$, による / sbj >

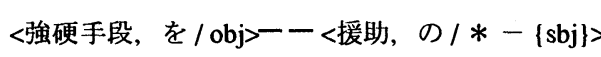

* : $\{$ sbj, obj, pac, lt(LevelTarget), dl(DeadLine) $\}$
二部グラフ(2) :

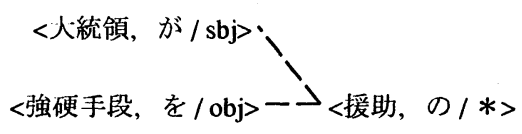

二部グラフ(4) :

〈強硬手段，を/obj>-ーく援助，の/*>

図 4 テキスト 3 のサ変動詞文とサ変名詞句に関する二部グラフ

\section{4 実験と考察}

支配従属構造照合による意味制約充足性の判定法の有効性を検証するために，新聞記事デー 夕 (朝日新聞社 1991) からサ変動詞文とサ変名詞句を含む 100 記事を無作為に抽出し, 各記事 に含まれるサ変動詞文とサ変名詞句の組のうち，両者の物理的な距離が最も近いもの 178 組を 対象として実験を行なった。サ変動詞文を含む文とサ変名詞句を含む文に対して形態素，構文， 意味的共起解析を行ない, 可能な支配従属構造のうち, 形態素, 構文, 意味的共起に関する選 好による総合評価点が最も高い構造を入力とした。なお，処理対象のサ変動詞文とサ変名詞句 は, サ変動詞の語幹がサ変名詞句の主要部であるため照応が成立する可能性が高いと考えられ るが，人間に照応が認められるのは 178 組中 95 組 $(53.4 \%)$ であった.

\section{1 照応判定成功率}

本手法による照応判定と人間による判定を比較した結果を表 3 に示す. 本手法と人間による 判定が，照応成立という解釈で一致したサ変動詞文とサ変名詞句は 77 組 $(43.2 \%)$, 不成立とい う解釈で一致したのは 56 組 $(31.5 \%)$ であった。この結果，本手法による判定成功率は $74.7 \%$ と なる．また，判定を誤った組のうち，人間には照応が認められるものを照応不成立と判定した 
組は 18 組 $(10.1 \%) ， そ の$ 逆は 27 組 $(15.2 \%)$ であった。

表 3 新聞記事を対象とした本手法の判定精度

\begin{tabular}{|c|c|c|r|}
\hline \multirow{2}{*}{$\begin{array}{c}\text { 人間による } \\
\text { 判定との比較 }\end{array}$} & \multicolumn{2}{|c|}{ 本手法による判定 } & \multirow{2}{*}{ 成功/失敗率 } \\
\hline \hline 一致 & $43.2 \%(77 / 178)$ & $31.5 \%(56 / 178)$ & $74.7 \%$ \\
\hline 不一致 & $15.2 \%(27 / 178)$ & $10.1 \%(18 / 178)$ & $25.3 \%$ \\
\hline
\end{tabular}

表 4 照応不成立と誤判定された原因の分析

\begin{tabular}{|l|r|}
\hline \multicolumn{1}{|c|}{ 原因 } & 誤り数 \\
\hline \hline 類義語等による従属語の言い換え & 10 \\
\hline サ変名詞句での従属語の追加 & 3 \\
\hline 従属語の主要部の削除 & 3 \\
\hline その他 & 2 \\
\hline
\end{tabular}

照応不成立と誤判定した 18 組について，その原因を分析した結果を表 4 に示す．最も多かっ た原因は，サ変名詞の従属語としてサ変動詞の従属語あるいはその一部が用いられず，その類 義語などの別の語が用いられていることであった。

失敗例 1 ただ, 歴訪を中止して湾岸危機の平和的解決に努める, といっても, 具体的な手立 てはそしい。(中略) 首相は 11 日朝，ASEAN 訪問中止の理由を記者団から聞かれ， 「米国とイラクの 9 日の外相会談が不調に終わって総合的に判断して決めた」。 失敗例 1 では, 「歴訪」と「訪問」の文字列照合に失敗するので，照応は成立しないと誤判定さ れた。

サ変動詞文では明示されていない語がサ変名詞句で初めて表現されているため，判定を誤っ た例を示す。

失敗例 2 しかし，期限切れ前に締結される今回の新特別協定によって，これまでの諸手当に 加え，日本人従業員の基本給と光熱水費を 91 年度から段階的に肩代わりし，

新中期防衛力整備計画の最終年度の 95 年度には，その全額を負担できる仕組みに なっている。(中略) 必要経費は約 2200 億円で, 旦本側負担分は, 95 年度に在 日駐留経費全体の約半分に達する見通しだ.

失敗例 2 の場合, 明示されていないサ变動詞文の主語が「日本側」であることがすでに推論さ れているならば，本手法をそのまま適用することによって照応が正しく捉えられ，推論の正し さが裏付けられる。しかし，明示されていない主語が「日本側」であるとの推論をサ変動詞文 を含む文から得られる情報だけに基づいて行なうことは容易ではない。むしろ，本手法による 
判定から得られる情報を暧昧性絞り込みの手がかりとして，より積極的に利用する方が容易で ある。サ変動詞文で明示されていない従属語に関する情報が完全には得られておらず，例えば， 主語が明示されていないことだけが分かっており，それが具体的に何であるかは分かっていな いならば，任意の文字列と照合がとれる節点を主語としてサ変動詞文の従属構造構造に加えて おけば，本手法の判定によって曖昧性絞り込みの手がかりが提供されるようになる.

人間には照応が認められないものを照応成立と䜋判定した 27 組についての原因は，すべて， サ変動詞文とサ変名詞句の間に照応が成立しないことを示す手がかりが，サ変動詞文とサ変名 詞句以外の部分にあることによるものであった，失敗例 3 では，サ変動詞文「フセイン・イラ ク大統領と意見を交換する」とサ変名詞句「意見交換」の間に照応が成立しないと判定するた めには,「フセイン国王との間で」の部分を参照しなければならない.

失敗例 3 同事務総長は空港で報道陣に対し,「わたしはいかなる和平案も携行していない. フセイン・イラク大統領と意見を交換しに行く」と手短に答え，ジュネーブで言及 したイラク軍撤退後の国連平和維持軍派遣の構想などには触れなかった。この後, 王宮に向かい，欧州 4 力国歴訪から 9 日に帰国したばかりのフセイン国王との間で， 意見交換を行った。

特に, 27 組中 21 組については，サ変名詞句がサ変名詞だけで構成されているために，照応が 成立しないことを示す情報がサ変名詞句からは得られなかった．今回の実験では，サ变動詞の 語幹がサ変名詞句の主要部である場合に対象を限定しているため, サ変名詞句がサ変名詞だけ で構成されている場合, 照応が成立する可能性が高いと考え，そのように判定している．実際， そのように判定することで，サ変名詞だけで構成されているサ変名詞句を含む 73 組のうち， 52 組 $(71.2 \%)$ について正しい判定が下されている.

本手法では，各記事に含まれるサ変動詞文とサ変名詞句の組のうち，両者の距離が最も近い ものを対象としてはいるが，サ変動詞文とサ変名詞句の距離に関する制約を課していないので, サ変名詞句がサ変名詞だけで構成されている場合，両者がどんなに離れていても照合成立と判 定される．距離に関するパラメータと算式を定めることは今後の課題である。

\section{2 曖昧性解消率}

本手法の判定によって照応が成立すると正しく判定された 77 組のサ変動詞文とサ変名詞句 について, 類似性が最も高いと判断された (全体で最も高い評価点が与えられた) 支配従属構造 の組を優先することによって，どの程度曖昧性が絞り込めるかを調べた．本手法への入力であ る支配従属構造から抽出されたサ変動詞文とサ変名詞句に関係する部分の解釈の可能性は一組 当たり平均 3.4 通り存在したが，これを構造照合によって 1.8 通りへ絞り込めた. 可能な解釈 の数が減少した組は 18 組であり，このうち 17 組は絞り込まれた解釈の中に，人間によって正 しいと判定される解釈が含まれていた。 また，18 組中 10 組については解釈を一意に決定でき， 
そのうち 9 組が人間によって正しいと判定される解釈であった.

\section{5 おわりに}

本稿では，テキストの対象分野を限定しない日英機械翻訳への応用を前提として，構築が困 難な知識や機構を必要とする意味合成による意味制約充足性の判定を支配従属構造照合による 判定で近似する方法を示し，実験を行なった，本手法による照応判定を第一次近似とみなせば， 比較的精度が高い結果が得られた背景には，英語では，先行文脈中に現れた語をそのまま反復 することは文体上の理由から希であり，別の語に言い換える場合が多いのに対し，日本語では 既出の語をそのまま繰り返す場合が多いことがあるものと考えられる．今回の実験では，処理 対象をサ変動詞文とサ変名詞句に限定し，文字列情報のみを用いて処理を行なったが，類義関 係を記述した意味体系が利用可能ならば，対象を拡げることも可能である.

謝辞 新聞記事データの利用を承諾下さった朝日新聞社の関係者の方々に感謝いたします.

\section{参考文献}

朝日新聞社 (1991). “朝日新聞全文記事情報 (CD-HIASK) 91 年版.” 日外アソシエーツ。 稲垣博人, 壁谷喜義, 小橋史彦 (1988). “意味連結パターンを用いた係り受け解析.” NL67-5, 情 報処理学会.

Jelinek, J., Yoshimi, T., Nishida, O., Tamura, N., and Murakami, H. (1995). "Text-Wide MT Grammar." In Proceedings of the 3rd Natural Language Processing Pacific Rim Symposium (NLPRS), pp. 449-454.

Kinoshita, S., Shimazu, M., and Hirakawa, H. (1993). "Better Translation with Knowledge Extracted from Source Text." In Proceedings of the 5th International Conference on Theoretical and Methodological Issues in Machine Translation (TMI), pp. 240-251. 小林義行, 徳永健伸, 田中穂積 (1996). “名詞の意味的共起情報を用いた複合名詞の解析.”自然 言語処理, 3 (1), 29-43.

那須川哲哉 (1995). “文脈情報を利用した自然言語文における構造的曖昧性の解消.”情報処理 学会論文誌, 36 (10), 2362-2370.

宇津呂武仁, 松本裕治, 長尾眞 (1992). “日英対訳文間の素性構造照合による統語的曖昧性の解

消.” 情報処理学会論文誌, 33 (12), 1555-1564.

\section{略歴}

吉見 毅彦： 1987 年電気通信大学大学院計算機科学専攻修士課程修了. 現在, シャープ (株) 情報商品開発研究所にて機械翻訳システムの研究開発に従事. 在職のまま, 1996 年より神戸大学大学院自然科学研究科博士課程在学中. 
Jiri Jelinek: チェコのプラハの Universita Karlova 卒業 (言語学・英語学・日 本語学). 1959 年以来, 日英機械翻訳実験中. 英国 Sheffield 大学日本研究所 専任講師を 1995 年退職. 1992 年より 1996 年までシャープ専任研究員.

(1996 年 4 月 2 日受付)

(1996 年 8 月 1 日 再受付)

(1996 年 9 月 19 日 採録) 